\title{
Pengembangan Sistem Informasi Manajemen Praktik Kerja Lapangan Penerapan Semua Program Studi Politeknik Negeri Tanah Laut
}

\author{
Muhammad Muslih Amirudin ${ }^{1)}$, Herpendi' ${ }^{2)}$, Veri Julianto ${ }^{3)}$, Eka Wahyu Sholeha ${ }^{4)}$ \\ 1)23)4) Jurusan Teknik Informatika, Politeknik Negeri Tanah Laut \\ J1. A Yani Km 6 Pelaihari Tanah Laut Kalimantan Selatan \\ 1) muhammad.muslih.amirudin@gmail.com \\ ${ }^{2)}$ herpendi@politala.ac.id \\ 3) veri@politala.ac.id \\ 4)ekawahyus@politala.ac.id
}

\begin{abstract}
Abstrak
Program Praktik Kerja Lapangan (PKL) diterapkan pada Politeknik Negeri Tanah Laut yang sebelumnya telah dibangun sistem pengelolaan proses kegiatan PKL yaitu Sistem Informasi Manajemen Praktik Kerja Lapangan (SIMPKL), dapat di akses pada laman https://simpkl.politala.ac.id. Hasil observasi penulis yang dilaksanakan pada saat menggunakan sistem tersebut, terdapat beberapa kekurangan yang ada pada SIMPKL. Adapun kekurangannya yaitu belum dilakukannya dinamisasi sistem berupa persentase penilaian akhir, batas waktu seminar, batas waktu pendaftaran seminar, batas waktu revisi, batas waktu pemberkasan, perbaikan tampilan modal pada jadwal seminar, muat ulang halaman secara otomatis setelah penginputan jadwal seminar, menu mahasiswa belum lulus PKL, menu mahasiswa selesai PKL, serta penambahan fitur user yaitu peserta seminar tidak perlu membawa kertas form melihat seminar, penulis menyarankan untuk langsung login pada sistem, yang diverifikasi oleh pembimbing. Kemudian perlu diterapkannya pada semua program studi yang ada di Politeknik Negeri Tanah Laut, karena saat ini masih diterapkan dalam program studi teknologi informasi. Solusi dari permasalahan yang telah dipaparkan penulis membangun Pengembangan Sistem Informasi Manajemen Praktik Kerja Lapagan untuk Penerapan Semua Program Studi pada Politeknik Negeri Tanah Laut dibangun menggunakan bahasa pemrograman Hypertext Markup Language (HTML), framework Codeigniter (CI) dan Hypertext Preprocesor (PHP), metode perancangan menggunakan Unified Modelling Language (UML) yang dirancang menggunakan Microsoft Visio, perancangan user interface menggunakan Cascading Style Sheet (CSS), JavaScript dan Balsamiq Mockup 3 sedangkan basis data yang digunakan adalah MySQLi.
\end{abstract}

Kata kunci: Praktik Kerja Lapangan (PKL), Pengembangan.

\begin{abstract}
Internship (PKL) program is being implemented on State Polytechnic of Tanah Laut. Previously, a system for managing internship activity has been built. The name is Sistem Informasi Manajemen Praktik Kerja Lapangan (SIMPKL), which can be accessed on https://simpkl.politala.ac.id webpage. Results from the author's observations carried out at the time when activity took place, there are some mistakes in SIMPKL. The mistakes are no system dynamizication in percentage of final assessment, the deadline of the seminar, the deadline for seminar registration, revision deadlines, filing deadlines, improvement of the display of modal on the seminar schedule, reload the page automatically after the entry of Seminar schedule, student menu has not graduated PKL, student menu finished PKL and user addition features that is seminar participants do not have to bring the seminar attendance form, the authors suggest to log in directly to the system, which is verified by the guide lecturer. It needs to be applied to all study programs on State Polytechnic of Tanah Laut, because currently it's only applied to information technology study program. The solutions for this problem has been presented by the author to build a Development of Internship Management Information System and it's Application to all Study Programs on State Polythecnic Of Tanah Laut using programming language Hypertext Markup Language (HTML), framework Codeigniter (CI) and Hypertext Prepocesor (PHP), design method using Unified
\end{abstract}


Modelling Language (UML) designed using Microsoft Visio, user interface design using Cascading Style Sheet (CSS), JavaScript and Balsamiq Mockup 3, while database using a MySQLi.

Keywords: Internship, Development.

\section{PENDAHULUAN}

Peraturan Menteri Tenaga Kerja dan Transmigrasi No. Per.22/Men/IX/2009 tentang Penyelenggaraan Pemagangan di Dalam Negeri, Pemagangan diartikan sebagai bagian dari sistem pelatihan kerja yang diselenggarakan secara terpadu antara pelatihan di lembaga pelatihan dengan bekerja secara langsung di bawah bimbingan dan pengawasan instruktur atau pekerja yang lebih berpengalaman dalam proses produksi barang dan jasa di perusahaan, dalam rangka menguasai keterampilan atau keahlian tertentu [1]. Program PKL juga diterapkan di kampus Politeknik Negeri Tanah Laut.

Sebelumnya telah dibangun sistem pengelolaan proses kegiatan PKL yaitu Sistem Informasi Manajemen Praktik Kerja Lapangan (SIMPKL), dapat dilihat pada laman https://simpkl.politala.ac.id. Pada sistem tersebut sudah berjalan mulai dari proses pendaftaran PKL, pemilihan tempat pelaksanaan PKL, penentuan waktu PKL, pemilihan dosen pembimbing, seminar hasil PKL sampai dengan penilaian akhir serta pemberkasan akhir PKL. Hasil observasi penulis yang dilaksanakan pada saat kegiatan tersebut berlangsung, terdapat beberapa kekurangan yang ada pada SIMPKL. Adapun kekurangannya yaitu belum dilakukannya dinamisasi sistem berupa persentase penilaian akhir, batas waktu seminar, batas waktu pendaftaran seminar, batas waktu revisi, batas waktu pemberkasan, perbaikan tampilan modal pada jadwal seminar, muat ulang halaman secara otomatis setelah penginputan jadwal seminar, menu mahasiswa belum lulus PKL, menu mahasiswa selesai PKL, serta penambahan fitur user yaitu peserta seminar tidak perlu membawa kertas form melihat seminar, penulis menyarankan untuk langsung login pada sistem, yang diverifikasi oleh pembimbing. Selain itu, sistem yang berjalan belum diterapkan disemua program studi yang ada di Politeknik Negeri Tanah Laut melainkan hanya pada program studi teknologi informasi saja. Oleh karena itu, penulis mengusulkan Pengembangan Sistem Informasi Manajemen Praktik Kerja Lapangan untuk Penerapan Semua Program Studi pada Politeknik Negeri Tanah Laut, penulis akan menggunakan desain pengujian black box.

\section{TINJAUAN PUSTAKA}

\subsection{Penelitian Terkait}

Berdasarkan penelusuran penulis terhadap beberapa literatur kepustakaan, terdapat beberapa penelitian sebelumnya yang sejenis dan berkaitan dengan topik Pengembangan Sistem Informasi Manajemen Praktik Kerja Lapangan untuk Penerapan Semua Program Studi pada Politeknik Negeri Tanah Laut.

Penelitian yang dilakukan oleh I Gede Ngurah Wira Pratama, I Gede Ngurah Anom Cahyadi Putra dan Aulia Iefan Datya dengan judul jurnal "Sistem Informasi Manajemen Praktik Kerja Lapangan Berbasis Website (Studi Kasus Program Studi Sistem Informasi Universitas Dhyana Pura Bali)". Penelitian bertujuan untuk membantu mahasiswa dalam pelaksanaan praktik kerja lapangan [2].

Penelitian yang kedua dilakukan oleh Teguh Andriyan dan Risky Aswi Ramadhani dengan judul jurnal "Rancang Bangun Sistem Informasi Praktik Kerja Lapangan Terintegrasi Menggunakan Webservice". Penelitian bertujuan untuk mengatasi permasalahan tersebut dalam penelitian ini dirancang dan dibangun Sistem Informasi Praktik Kerja Lapangan (SIM PKL) yang terintegrasi dengan data Sistem Informasi Akademik UN PGRI Kediri menggunakan RESTFul Webservice [3].

Penelitian yang ketiga dilakukan oleh Muhammad Arifin dengan judul jurnal "Analisa dan Perancangan Sistem Informasi Praktik Kerja Lapangan (PKL) pada Instansi/Perusahaan". Penelitian bertujuan untuk mengorganisasi kegiatan PKL secara rapi antara peserta dan perusahaan/ intansi tempat magang sehingga semua pihak dapat merasakan manfaat dari kegiatan PKL [4].

Penelitian yang keempat dilakukan oleh S.Thya Safitri dan Didi Supriyadi judul jurnal "Rancang Bangun Sistem Informasi Praktik Kerja Lapangan Berbasis Web dengan metode 
Waterfall". Penelitian ini bertujuan untuk menampilkan informasi yang dibutuhkan dalam kegiatan PKL, memanipulasi data yang digunakan yang akan digunakan dalam kegiatan PKL [5].

Penelitian yang kelima dilakukan oleh Abdul Gani dan Wire Bagye judul jurnal "Sistem Informasi Praktik Kerja Industri pada SMK Islam Sirajul Huda Paok Dandak". Penelitian ini bertujuan untuk memberikan informasi kepada siswa peserta praktik kerja industri (Prakerin). Prakerin merupakan kegiatan Prakyek Kerja Industri, dimana siswa dilatih terjun langsung ke dunia kerja berdasarkan kemampuan yang dimilliki dimana sebelumnya belajar di sekolah kemudian diterapkan langsung di industri atau perusahaan tempat praktik kerja industri. Adapun tujuan penelitian ini yaitu tentang format pelaporan kegiatan Prakerin, jadwal kunjungan guru pembimbing, dan informasi waktu berakhir kegiatan Prakerin [6].

Penelitian yang keenam dilakukan oleh Abdul Rohman dan Herlawati dengan judul jurnal "Sistem Informasi Praktik Kerja Industri pada SMK Taruna Bangsa Bekasi". Penelitian ini bertujuan untuk memudahkan tiap siswa dalam mendapatkan informasi dan pihak sekolah dalam mengolah data mulai dari proses pengajuan, praktik kerja industri sampai dengan laporan [7].

Adapun persamaan penelitian ini dengan penelitian di atas adalah seluruhnya membahas masalah terkait dengan kegiatan Praktik Kerja Lapangan. Tetapi, mempunyai fokus penelitian yang berbeda. Adapun fokus penelitian ini adalah untuk melakukan proses dinamisasi sistem yang telah dibangun sebelumnya pada Politeknik Negeri Tanah Laut. Meskipun ada sebagian beberapa kesamaan dengan keenam penelitian di atas, yakni membahas Praktik Kerja Lapangan, namun terdapat perbedaan-perbedaan dalam hal variabel, metode, teori yang dikembangkan maupun tempat penelitian. Variabel dalam penelitian ini adalah Pengembangan Praktik Kerja Lapangan dengan subjek 5 orang yaitu admin, dosen, mahasiswa dan peserta.

\subsection{Sistem Informasi Manajemen}

Sistem informasi manajemen adalah sebuah sistem manusia atau mesin yang terpadu untuk menyajikan informasi guna mendukung fungsi operasi manajemen dan pengambilan keputusan dalam suatu organisasi. Sistem informasi manajemen juga merupakan sebuah organisasi yang memiliki informasi bermanfaat dalam pembuatan keputusan manajemen, baik yang menyangkut keputusan-keputusan rutin maupun keputusan strategis. Sistem informasi manajemen memiliki karakteristik yaitu dapat beroperasi pada tugas-tugas yang struktur, meningkatkan efisiensi dan mengurangi biaya, menyediakan laporan untuk keperluan pengambilan keputusan dan mempermudah akses informasi untuk keperluan manajemen [8].

\subsection{Basis Data}

Basis Data adalah sebuah kumpulan data yang saling berhubungan dengan logis dan merupakan sebuah penjelasan dari data tersebut, kemudian didesain untuk menemukan data yang dibutuhkan oleh instansi (organisasi). Pada basis data, semua data diintegrasikan dengan menghindari terjadinya duplikasi suatu data [9].

\subsection{Entity Relationship Diagram (ERD)}

Entity Relationship diagram (ERD) merupakan pemodelan awal basis data yang paling banyak digunakan. ERD dikembangkan berdasarkan teori himpunan dalam bidang matematika. ERD digunakan untuk pemodelan basis data relasional [10].

\subsection{Unified Modelling Language (UML)}

UML menggunakan notasi grafis untuk menampilkan desain proyek perangkat lunak. UML berguna untuk mkengeksplorasi desain potensial serta memvalidasi desain arsitektur perangkat lunak. UML memiliki banyak jenis diagram dan masing-masing dari diagram tersebut memiliki tujuan yang berbeda agar dapat melihat sistem dari berbagai sudut pandang yang berbeda [10].

\subsection{Diagram Use Case}

Diagram Use case digunakan untuk mengetahui fungsi apa saja yang ada di dalam sebuah sistem informasi dan siapa saja yang berhak menggunakan fungsi-fungsi yang ada [10]. 


\subsection{Black Box}

Pengujian sistem berdasarkan Black Box Testing adalah pengujian perangkat lunak dari segi fungsional tanpa menguji desain atau suatu kode program yang dibuat. Pengujian ditujukan agar mengetahui apakah fungsi-fungsi, masukan dan keluaran perangkat lunak sesuai dengan spesifikasi yang dibutuhkan [10].

\section{METODE PENELITIAN}

Metode yang digunakan dalam penelitian ini terbagi menjadi bebrapa tahap yaitu; 1). Pengumpulan data, 2) Analisis data, 3). Development system.

\subsection{Pengumpulan Data}

Pengumpulan data dilakukan dengan melakukan wawancara dengan pembangun sistem SIMPKL sebelumnya dan koordinator praktik kerja industri program studi teknologi informasi terkait dengan proses bisnis untuk dilakukan tahap pengembangan. Selain itu dengan melakukan observasi langsung sistem yang sudah berjalan.

\subsection{Analisis Data}

Hasil dari wawancara dengan pembangun sistem SIMPKL sebelumnya dan koordinator praktik kerja industri program studi teknologi informasi menghasilkan suatu ide yang dianalisis secara mendalam dalam menyelesaikan permasalahan yang dihadapi. Analisis data dari wawancara dan observasi ini memunculkan sebuah ide untuk membangun suatu teknologi informasi dalam membantu proses pengelolan data di Prakerin Politeknik Negeri Tanah Laut serta membantu menumbuhkan partisipasi.

\subsection{Development System}

Metode pengembangan yang dilakukan untuk membangun Pengembangan Sistem Informasi Manajemen Praktik Kerja Lapangan untuk Penerapan Semua Program Studi pada Politeknik Negeri Tanah Laut adalah metode prorotipe, dalam metode tersebut, perangkat lunak yang dihasilkan kemudian dipresentasikan kepada pengguna, dan pengguna tersebut diberikan kesempatan untuk memberikan masukan dan kritikan, sehingga perangkat lunak yang dihasilkan sesuai dengan kebutuhan dan keinginan pengguna. Perubahan perangkat lunak dapat dilakukan berkali-kali hingga dicapai kesepakatan bentuk dari perangkat lunak yang akan dikembangkan.

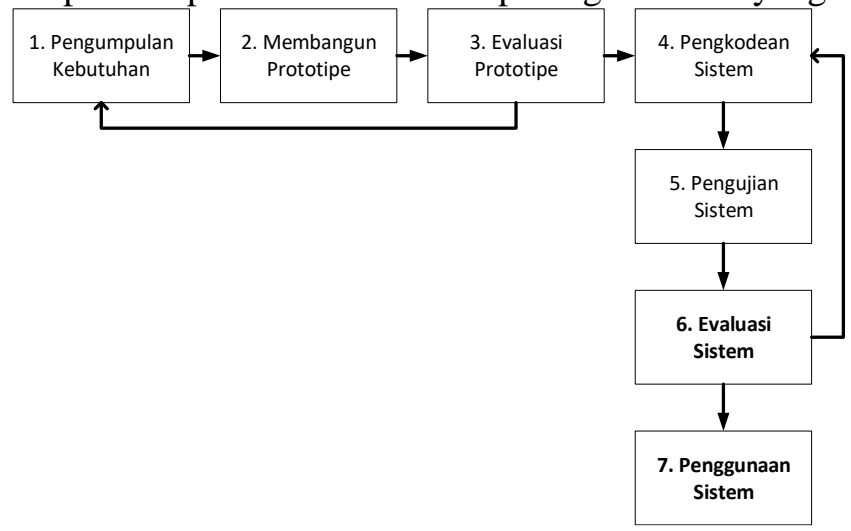

Gambar 1 Metode prototipe

Gambar 1 adalah Metode Prototipe, tahapan metode prototipe, sebagai berikut:

a) Pengumpulan kebutuhan, pengembang mendefinisikan format perangkat lunak, mengidentifikasikan kebutuhan dan sistem yang dibuat.

b) Membangun prototype, membangun prototipe dengan membuat perancangan sementara yang berfokus penyajian kepada pengguna (contoh membuat input dan format output).

c) Evaluasi prototype, tahap ini dilakukan oleh pengguna, apakah prototipe yang dibangun, sudah sesuai dengan keinginan dan kebutuhan pengguna atau belum. Jika tidak sesuai, 
prototipe akan direvisi dengan mengulangi langkah-langkah sebelumnya. Tapi jika sudah sesuai, maka langkah selanjutnya akan dilaksanakan.

d) Pengkodean sistem, pada tahap ini prototipe yang sudah disepakati diterjemahkan ke dalam bahasa pemrograman yang sesuai. Bahasa pemrograman yang digunakan adalah Hypertext Markup Language (HTML), menggunakan framework Codeigniter (CI) dan Hypertext Preprocesor (PHP), sedangkan basis data yang digunakan adalah MySQLi.

e) Pengujian sistem, setelah sistem sudah menjadi suatu perangkat lunak yang siap pakai, maka perangkat lunak harus di tes dahulu sebelum digunakan. Hal ini bertujuan untuk meminimalisirkan kesalahan perangkat lunak tersebut. Pengujian dilakukan dengan black box. Kasus uji yang dibuat untuk melakukan pengujian black box harus dibuat dengan kasus benar dan kasus salah, misalkan untuk kasus proses login maka kasus uji yang dibuat adalah jika user memasukkan nama pemakai (username) dan kata sandi (password) yang benar. Jika user memasukkan nama pemakai (username) dan kata sandi (password) yang salah, misalnya nama pemakai benar tapi kata sandi salah, atau sebaliknya, atau keduanya salah.

f) Evaluasi sistem, pada tahap ini pengguna mengevaluasi sistem yang sudah dibuat sudah sesuai yang diinginkan. Jika tidak, maka pengembang akan mengulangi langkah ke 4 dan ke 5. Tapi jika iya, maka langkah ke 7 akan dilakukan.

g) Penggunaan sistem, perangkat Lunak yang telah diuji dan diterima pengguna siap digunakan.

\section{PEMBAHASAN}

\subsection{Analisis Sistem yang Berjalan}

Analisis sistem yang berjalan dapat dilihat pada Gambar 2.

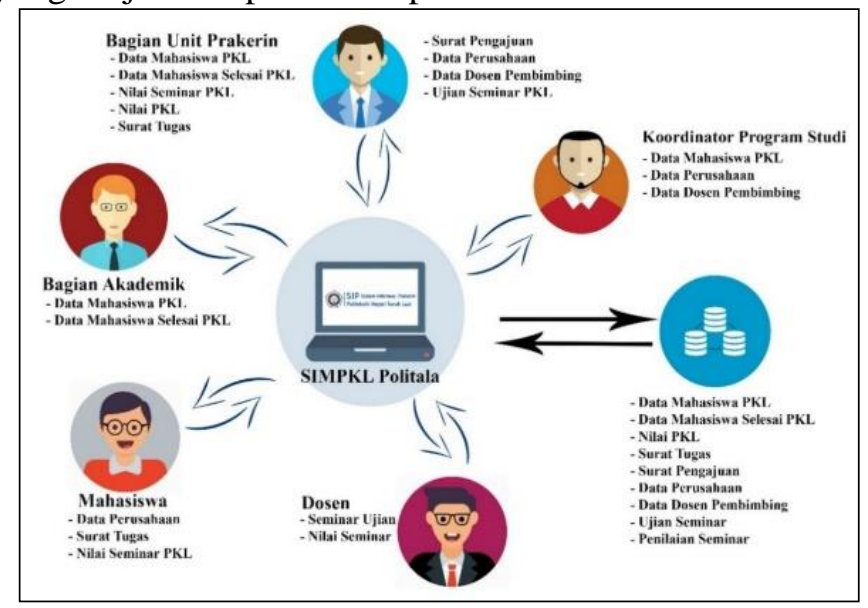

Gambar 2. Analisis sistem yang berjalan

Pada tahap awal bagian akademik merilis data mahasiswa dari setiap program studi yang dapat mengikuti Prakerin atau tidak. Data tersebut akan menjadi acuan dalam sistem bahwa nama-nama tersebutlah yang akan dapat melakukan kegiatan Praktik Kerja Lapangan (PKL). Adapun mahasiswa juga dapat mengusulkan data perusahaan jika perusahaan yang dia inginkan tidak ada di list prakerin akan tetapi nantinya perusahaan yang di usulkan tersebut dapat dipilih jika sudah di validasi admin (Prakerin atau staff prakerin) statusnya.

Setiap perusahaan hanya boleh diisi maksimal 3 orang setiap program studi. Setelah mahasiswa mendapatkan username password mahasiswa harus melengkapai data dirinya sebelum memilih perusahaan yang akan di pilih. Data yang diisi harus valid (form biodata). Jika mahasiswa sudah memilih perusahaan maka mahasiswa harus membuat proposal dan ditandatangani oleh ketua jurusan masing-masing program studi. Proposal tersebut akan di serahkan ke staff prakerin untuk dibuatkan surat permohonan magang. Selanjutnya jika mahasiswa sudah dinyatakan diterima PKL maka mahasiswa dapat mengunggah surat balasan dari perusahaan. Sehingga status mahasiswa sudah diterima PKL dengan terlebih dhului di validasi oleh koordinator prakerin tiap 
program studi atau staff prakerin. Surat balasan ini sebagai dasar dalam pembuatan surat tugas untuk pertama kali mahasiswa akan pergi melaksanakan kegiatan PKL.

Tahap selanjutnya koordinator tiap program studi mengevaluasi mahasiswa yang sudah dapat atau belum tempat magang di tahun dilaksanakan kegaiatan PKL. Tahap selanjutnya ketika dinyatakan semua mahasiswa sudah mendapatkan tempat magang maka proses (SIG Tempat PKL) berjalan. Mahasiswa ketika berada di minggu pertama di tempat PKL melakukan update data pada menu perusahaan. Koordinator program studi melakukan pembagian dosen pembimbing. Dosen akan dapat login secara langsung dengan username dan password kepegawaian. Tahap selanjutnya yaitu Mahasiswa ketika diakhir kegiatan PKL meminta sertifikat PKL (template akan disediakan default pada aplikasi). Nilai PKL dan surat keterangan bahwa perusahaan menggunakan aplikasi yang digunakan, foto terbaik saat PKL dan video jika ada. Mahasiswa juga diperintahkan mengisi kuisioner tanggapan terhadap keadaan tempat magang. Mahasiswa dapat mengajukan permohonan seminar lewat aplikasi jika (form bimbingan bimbingan sudah minimal 5 kali) dan mendapat persetujuan dari pembimbing. Kemudian koordinator akan membuatkan jadwal sidang bagi mahasiswa yang sudah diijinkan untuk melakukan seminar.

Dosen Penguji dan Dosen Pembimbing melakukan proses pengujian dengan membuka akun masingmasing. Kemudian akan otomatis melihat siapa yang akan diuji dan dibimbing. Terdapat form penilaian yang secara fungsi bisa sementara dan bisa fixing ketika divalidasi. Mahasiswa melakukan proses revisi setelah melakukan seminar (form revisi). Sesuai dengan waktu yang ditentukan. Dosen dapat merubah nilai mahasiswa yang diuji jika data belum divalidasi (status). Mahasiswa dapat mencetak lembar selesai revisi jika seluruh dosen penguji dan pembimbing melakukan validasi nilai dan menekan tombol selesai revisi. Mahasiswa dapat mengupload berkas selesai seminar. Kemudian koordinator program studi melakukan validasi unggah sehingga mahasiswa dapat mencetak bukti selesai PKL baik secara pelaksanaan, seminar atau administrasi. Status selesai akan masuk dan dapat dilihat oleh akademik.

\subsection{Analisis Sistem yang Diusulkan}

Analisis sistem yang diusulkan dapat dilihat pada Gambar 3.

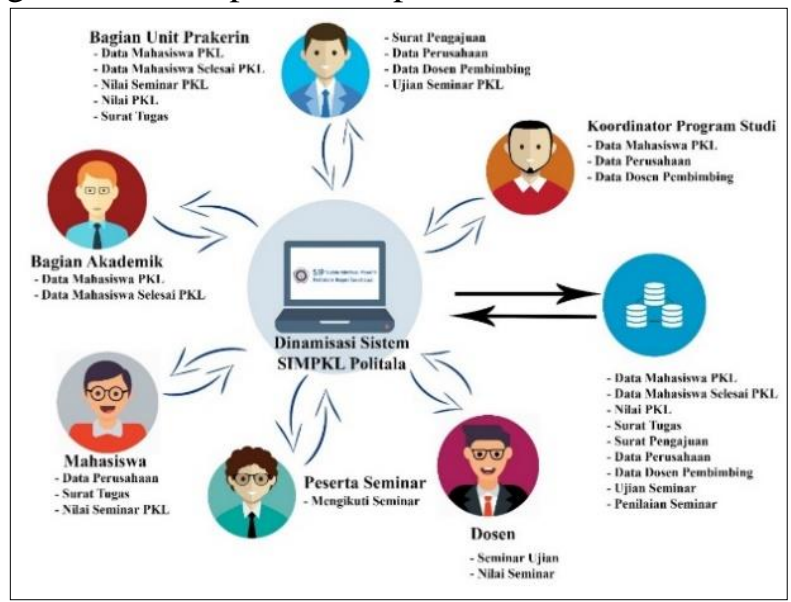

Gambar 3. Analisis sistem yang diusulkan

Dinamisasi sistem merupakan proses menyederhanakan suatu proses, seperti perhitungan dilakukan secara otomatis, pengingat secara otomatis dan sebagainya. Adapun perbedaan dengan sistem terdahulu belum adanya proses dinamisasi pada sistem yaitu berupa persentase penilaian akhir, batas waktu seminar, batas waktu pendaftaran seminar, batas waktu revisi, batas waktu pemberkasan, perbaikan tampilan modal pada jadwal seminar, muat ulang halaman secara otomatis setelah penginputan jadwal seminar, menu mahasiswa belum selesai PKL, menu mahasiswa selesai PKL, serta penambahan fitur user yaitu peserta seminar tidak perlu membawa kertas form melihat seminar, penulis menyarankan untuk langsung login pada sistem, yang diverifikasi oleh pembimbing. Selain itu, sistem yang berjalan belum diterapkan disemua program studi yang ada di Politeknik Negeri Tanah Laut melainkan hanya pada program studi teknologi informasi. Adapun parameter yang menyatakan sistem tersebut dinamis 
yaitu proses penyimpanan nilai pada variabel tidak lagi dengan nilai yang tersimpan dalam memori sementara sistem melainkan langsung dari database kemudian dieksekusi secara otomatis.

\subsection{Entity Relationship Diagram (ERD)}

Berikut adalah rancangan Pengembangan Sistem Informasi Manajemen Praktik Kerja Lapangan untuk Penerapan Semua Program Studi pada Politeknik Negeri Tanah Laut, dapat dilihat pada gambar 4.

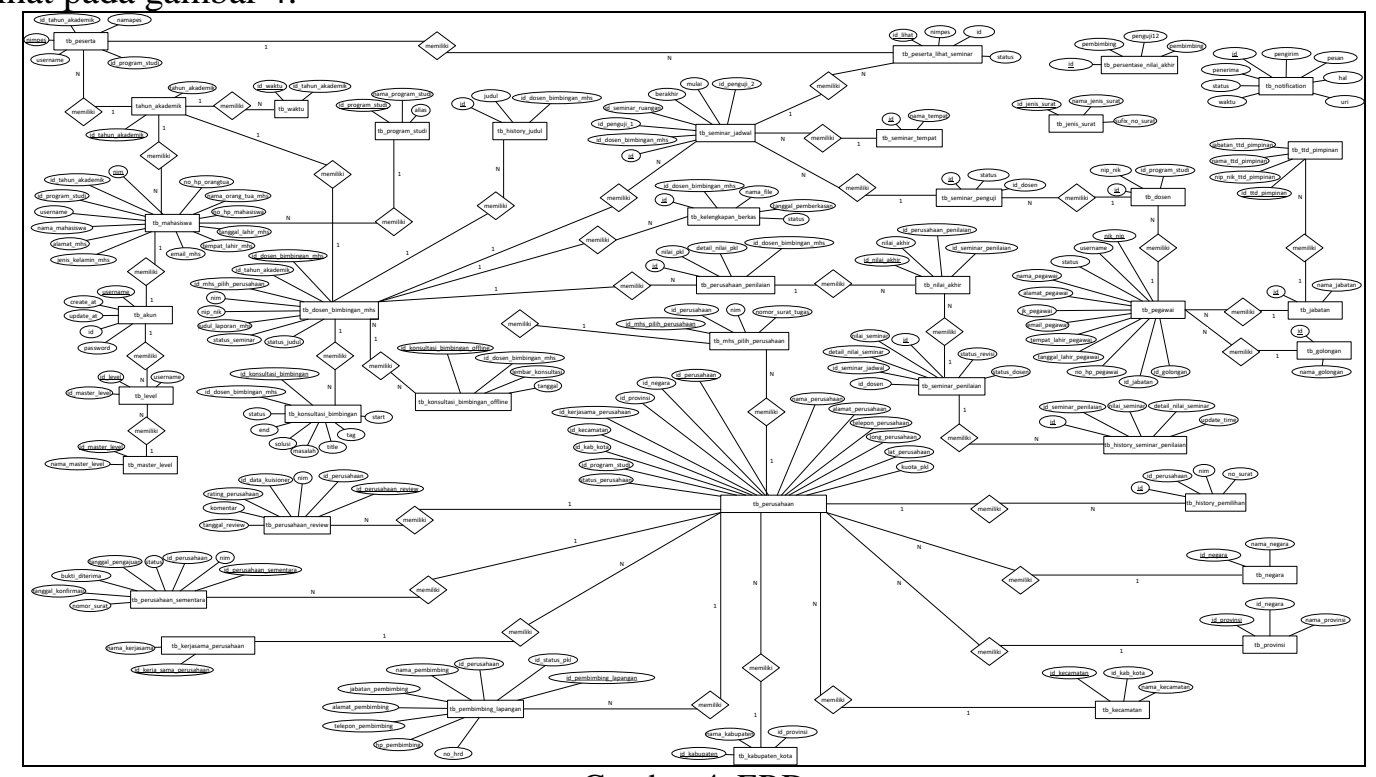

Gambar 4. ERD

Gambar 4 adalah alur database yang terdiri atas empat puluh satu entitas, setiap entitas mewakili nama tabel yang ada di database Pengembangan Sistem Informasi Manajemen Praktik Kerja Lapangan untuk Penerapan Semua Program Studi pada Politeknik Negeri Tanah Laut. Setiap atribut yang ada mewakili kolom-kolom yang ada pada database. Relasi yang menghubungkan entitas-entitas sesuai peranannya, bobot peranan entitas dapat dilihat pada kardinalitasnya.

\subsection{Diagram Use Case}

Berikut adalah rancangan diagram use case Pengembangan Sistem Informasi Manajemen Praktik Kerja Lapangan untuk Penerapan Semua Program Studi pada Politeknik Negeri Tanah Laut, dapat dilihat pada gambar 5.

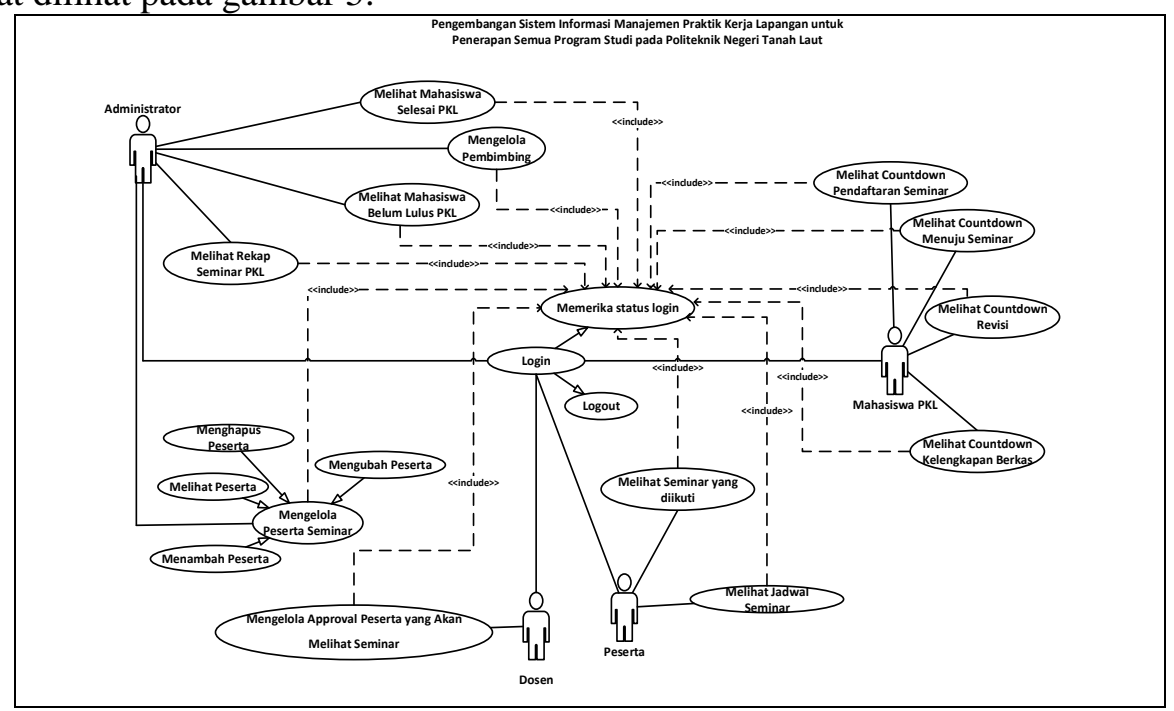

Gambar 5. Diagram Use Case 
Gambar 5 adalah Diagram Use Case Pengembangan Sistem Informasi Manajemen Praktik Kerja Lapangan untuk Penerapan Semua Program Studi pada Politeknik Negeri Tanah Laut memiliki 4 jenis pengguna yaitu Admin, Dosen, Mahasiswa dan Peserta Seminar.

\subsection{Implementasi Aplikasi}

Berikut adalah implementasi dari Pengembangan Sistem Informasi Manajemen Praktik Kerja Lapangan untuk Penerapan Semua Program Studi pada Politeknik Negeri Tanah Laut, dapat dilihat pada gambar 6 berikut.

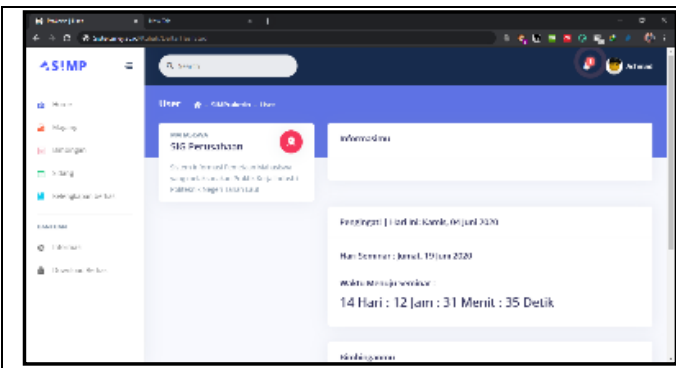

(a)

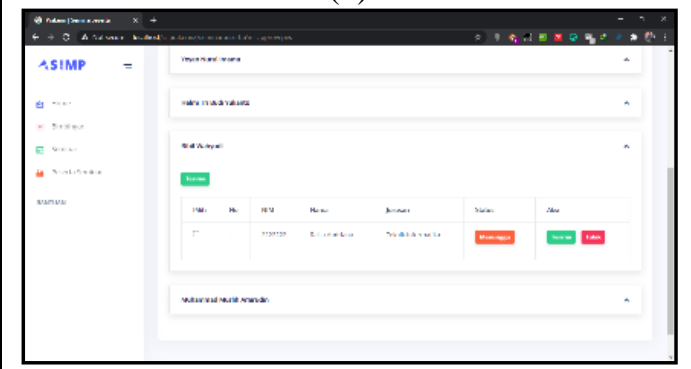

(c)

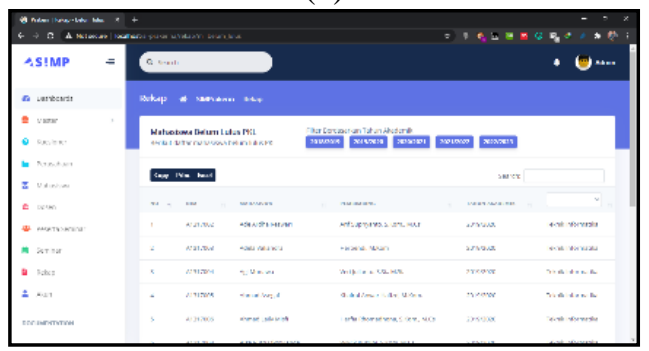

(e)

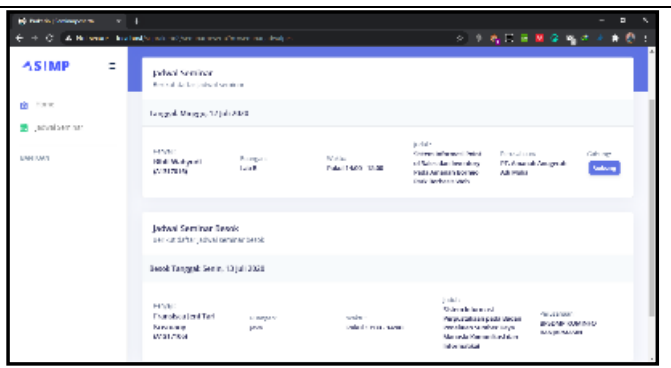

(b)

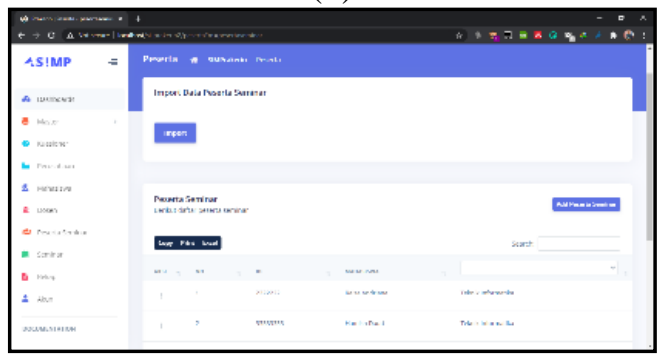

(d)

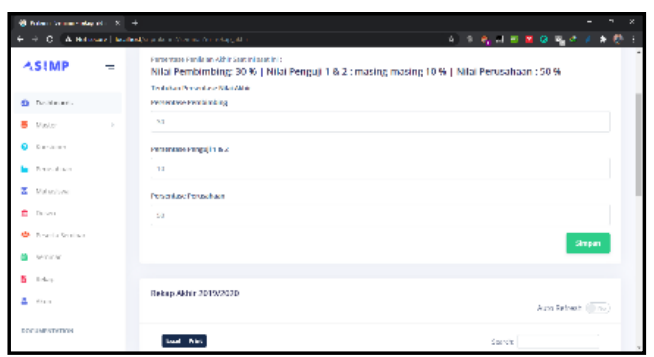

(f)

Gambar 6. Implementasi Antarmuka:, a. Halaman Dashboard Mahasiswa (Mahasiswa),

b. Halaman Jadwal Seminar (Peserta), c. Halaman Approval Peserta (Dosen), d. Halaman Peserta Seminar (Admin), e. Halaman Mahasiswa Belum Lulus PKL (Admin), f. Halaman Rekap Prakerin (Admin)

\subsubsection{Halaman Dashboard Mahasiswa (Mahasiswa)}

Gambar 6c antarmuka dashboard mahasiswa yang dapat diakses oleh mahasiswa. Mahasiwa dapat mengetahui waktu hitung mundur menuju seminar dimana jadwal telah ditentukan oleh admin.

\subsubsection{Halaman Jadwal Seminar (Peserta)}

Gambar $6 \mathrm{~g}$ antarmuka jadwal seminar yang dapat diakses oleh peserta seminar. Peserta dapat mengetahui jadwal seminar mahasiswa penyaji seminar pada hari ini dan esok. Peserta juga dapat melakukan gabung seminar. Untuk proses approval dilakukan oleh dosen pembimbing penyaji seminar. 


\subsubsection{Halaman Approval Peserta (Dosen)}

Gambar 6i adalah antarmuka approval peserta yang dapat diakses oleh dosen pembimbing. Dosen pembimbing dapat melakukan proses approval yaitu menolak peserta atau menerimanya untuk bergabung mengikuti seminar anak bimbingannya (mahasiswa penyaji).

\subsubsection{Halaman Peserta Seminar (Admin)}

Gambar $6 \mathrm{j}$ antarmuka peserta seminar yang dapat diakses oleh admin. Admin dapat melakukan proses lihat peserta, menambahkan peserta, mengedit peserta dan menghapus peserta.

\subsubsection{Halaman Mahasiswa Belum Lulus PKL (Admin)}

Gambar 6k antarmuka mahasiswa belum lulus PKL yang dapat diakses oleh admin. Admin dapat mengetahui mahasiswa yang belum lulus sesuai dengan tahun akademik yang dipilih.

\subsubsection{Halaman Rekap Prakerin (Admin)}

Gambar $6 \mathrm{~m}$ antarmuka rekap prakerin yang dapat diakses oleh admin. Admin dapat mengetahui rekap prakerin pada tahun akademik yang telah ditentukan. Admin juga dapat

\subsection{Pengujian Aplikasi}

Pengujian dilakukan dengan menggunakan metode black-box testing. Pengujian dilakukan pada 03 Agustus 2020 oleh dua orang user.

\begin{tabular}{|c|c|c|c|}
\hline No & Nama Pengujian & Hasil & Keterangan \\
\hline 1. & Fitur Halaman Dashbaord Mahasiswa & Valid & Fungsional fitur Countdown Menuju Seminar dan Revisi \\
\hline 2. & Fitur Halaman Jadwal Seminar Peserta & Valid & $\begin{array}{l}\text { Fungsional fitur Tampil Jadwal Semianr serta gabung } \\
\text { Seminar }\end{array}$ \\
\hline 3. & Fitur Approval Peserta (Dosen) & Valid & Fungsional fitur approval terima atau tolak peserta seminar \\
\hline 4. & Fitutr Peserta Seminar (Admin) & Valid & Fungsional fitur CRUD peserta seminar \\
\hline 5. & Fitur Menu Mahsiswa Belum Lulus & Valid & Fungsional fitur tampil mahasiswa belum lulus sesuai tahun \\
\hline 6. & Fitur Menu Rekap Prakerin & Valid & Fungsional fitur update persentase penilaian akhir \\
\hline
\end{tabular}

\section{KESIMPULAN}

Kesimpulan yang dapat penulis kemukakan, sebagai berikut:

a. Telah dibangunnya Pengembangan Sistem Informasi Manajemen Praktik Kerja Lapangan untuk Penerapan Semua Program Studi pada Politeknik Negeri Tanah Laut.

b. Tercapainya pengujian Pengembangan Sistem Informasi Manajemen Praktik Kerja Lapangan untuk Penerapan Semua Program Studi pada Politeknik Negeri Tanah Laut menggunakan black box.

\section{DAFTAR PUSTAKA}

[1] Kementerian Tenaga Kerja dan Transmigrasi, Peraturan Menteri Tenaga Kerja dan Transmigrasi Republik Indonesia Nomor PER.22/MEN/IX/2009 Tentang Penyelenggaraan Pemagangan di Dalam Negeri. Indonesia, 2009.

[2] I. G. N. W. Pratama, I. A. C. Putra, and A. I. Datya, "Sistem Informasi Manajemen Praktik Kerja Lapangan Berbasis Website (Studi Kasus Program Studi Sistem Informasi Universitas Dhyana Pura Bali)," J. Teknol. Inf. dan Komput., vol. 3, no. 1, pp. 342-351, 2017.

[3] T. Andriyanto and R. A. Ramadhani, "Rancang Bangun Sistem Informasi Praktik Kerja Lapangan Terintegrasi Menggunakan Webservice," Simetris J. Tek. Mesin, Elektro dan Ilmu Komput., vol. 7, no. 2, pp. 551-558, 2016.

[4] M. Arifin, "Analisa dan Perancangan Sistem Informasi Praktik Kerja Lapangan pada Instansi/Perusahaan," Simetris J. Tek. Mesin, Elektro dan Ilmu Komput., vol. 5, no. 1, pp. 49-56, 2014.

[5] S. T. Safitri and D. Supriyadi, "Rancang Bangun Sistem Informasi Praktek Kerja Lapangan Berbasis Web dengan Metode Waterfall," J. Infotel, vol. 7, no. 1, pp. 69-74, 2015. 
[6] A. Gani and W. Baye, "Sistem Informasi Praktek Kerja Industri Pada SMK Islam Sirajul Huda Paok Dandak," J. Manaj. Inform. dan Sist. Inf., vol. 1, no. 1, pp. 52-56, 2018.

[7] A. Rohman and H. Herlawati, "Sistem Informasi Praktek Kerja Industri Pada SMK Taruna Bangsa Bekasi," Bina Insa. ICT J., vol. 4, no. 2, pp. 197-208, 2017.

[8] A. Juansyah, "Pembangunan Aplikasi Child Tracker Berbasis Assisted - Global Positioning System ( A-GPS ) Dengan Platform Android," J. Ilm. Komput. dan Inform., vol. 1, no. 1, pp. 1-8, 2015.

[9] Indrajani, Database Design. Jakarta: Elex Media Komputindo, 2015.

[10] R. A. Sukamto and M. Shalahuddin, Rekayasa Perangkat Lunak (Terstruktur dan Berorientasi Objek). Bandung: INFORMATIKA, 2016.

\section{Biodata Penulis}

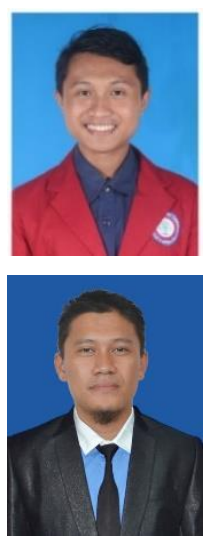

Muhammad Muslih Amirudin, kelahiran Pantai Linuh 19 Maret 1999. Saat artikel ini ditulis, penulis berstatus mahasiswa di Politeknik Negeri Tanah Laut. Penulis memulai perkuliahan di jurusan Teknik Informatika sejak tahun 2017. (M.Kom). Menjadi Dosen Tetap di lingkungan Politeknik Negeri Tanah Laut terhitung Januari 2016.

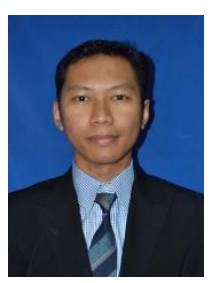

Veri Julianto, M.Si, lahir di Gunung Makmur pada tanggal 11 Juli 1990. Memperoleh gelar S.Si dalam bidang Matematika di FMIPA UNLAM kemudian melanjutkan pendidikan Strata 2 di jurusan Komputasi Institut Teknologi Bandung dan memperoleh gelar M.Si pada tahun 2004. Selama penulis menempuh pendidikan Strata 2, penulis memfokuskan untuk mengkaji bidang Optimasi. Setelah memperoleh gelar Magister, penulis bekerja menjadi Dosen di jurusan Teknik Informatika Politeknik Negeri Tanah Laut mulai tahun 2014.

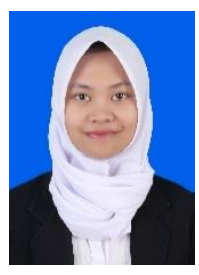

Eka Wahyu Sholeha, M.Kom, lahir di Pelaihari pada tanggal 25 Agustus 1996. Lulus Sekolah Menengah Atas (SMA) Negeri 1 Pelaihari tahun 2014. Tahun 2014 mulai kuliah di Universitas Amikom Yogyakarta Program Studi Sistem Informatika dan lulus sarjana pada tahun 2017 dengan gelar S.Kom. Pendidikan pascasarjana Program Studi Magister Teknik Informatika (S-2) ditempuh tahun 2018 dan lulus tahun 2019 dengan gelar Magister Komputer (M.Kom). Menjadi Dosen di lingkungan Politeknik Negeri Tanah Laut terhitung September 2020. 